\title{
An Externally Brooding Acorn Worm (Hemichordata, Enteropneusta, Torquaratoridae) from the Russian Arctic
}

\author{
KAREN J. OSBORN ${ }^{1, *}$, ANDREY V. GEBRUK ${ }^{2}$, ANTONINA ROGACHEVA ${ }^{2}$, AND \\ NICHOLAS D. HOLLAND ${ }^{3}$ \\ ${ }^{1}$ Department of Invertebrate Zoology, Smithsonian Institution, National Museum of Natural History, \\ Washington, DC 20013-7012; ${ }^{2}$ P. P. Shirshov Institute of Oceanology, Russian Academy of Sciences, \\ Moscow 117997, Russia; and ${ }^{3}$ Marine Biology Research Division, Scripps Institution of Oceanography, \\ University of California at San Diego, La Jolla, California 92093
}

\begin{abstract}
A single specimen of a previously undescribed acorn worm in the family Torquaratoridae was trawled from a bottom depth of about $350 \mathrm{~m}$ in the Kara Sea (Russian Arctic). The new species is the shallowest of the exclusively deep-sea torquaratorids found to date, possibly an example of high-latitude emergence. On the basis of ribosomal DNA sequences and morphology, the worm is described here as the holotype of Coleodesmium karaensis n. gen., n. sp. It is most similar in overall body shape to the previously described enteropneust genus Allapasus, but is uniquely characterized by a tubular component of the proboscis skeleton ensheathing the collar nerve cord. Additionally, within the proboscis, the sparseness of the musculature of $C$. karaensis clearly distinguishes it from the much more muscular members of Allapasus. The holotype is a female bearing about a dozen embryos on the surface of her pharyngeal region, each recessed within a shallow depression in the dorsal epidermis. The embryos, ranging from late gastrula to an early stage of coelom formation, are a little more than $1 \mathrm{~mm}$ in diameter and surrounded by a thin membrane. Each embryo comprises an external ectoderm of monociliated cells (not arranged in obvious ciliated bands) and an internal endo-mesoderm; the blastopore is closed. In the most advanced embryos, the anterior coelom is starting to constrict off from the archenteron. Coleodesmium karaensis is the first enteropneust (and indeed the first hemichordate) found brooding embryos on the surface of the mother's body.
\end{abstract}

Received 20 April 2013; accepted 2 October 2013.

* To whom correspondence should be addressed. E-mail: osbornk@ si.edu

\section{Introduction}

The phylum Hemichordata is divided into two classes: Pterobranchia and Enteropneusta. Pterobranchs, represented by about 30 described species, are found from littoral to continental slope depths, whereas enteropneusts, with about 100 described species, live predominantly in the littoral zone (Hyman, 1959) but have occasionally been found in the deep sea. By the end of the twentieth century, the following three deep-living enteropneusts had been described, one in each of the established families of the class: Glandiceps abyssicola Spengel, 1893 (family Spengelidae, 4570 m), Glossobalanus tuscarorae Belichov, 1971 (family Ptychoderidae, $8100 \mathrm{~m}$ ), and Saxipendium coronatum Woodwick and Sensenbaugh, 1985 (family Harrimaniidae, $2478 \mathrm{~m})$.

The number of deep-living enteropneusts recently increased markedly with the description of an additional harrimaniid, Saxipendium implicatum Holland et al., 2012a (3034 m) and six new species in the newly recognized family Torquaratoridae. The latter are Torquarator bullocki Holland et al. 2005 (1901 m), Tergivelum baldwinae Holland et al., 2009 (3952 m), Allapasus aurantiacus Holland et al., 2012b (2994 m); Tergivelum cinnabarinum Priede et al., 2012 (2493 m), Allapasus isidis Priede et al., 2012 (2622 m), and Yoda purpurata Priede et al., 2012 (2622 m). Smith et al. (2005), Holland et al. (2005, 2009, 2012b), Anderson et al. (2011), Osborn et al. (2012), and Priede et al. (2012) discussed the ecology of torquaratorid enteropneusts. All known members of the family have been found living epibenthically on the surface of the deep-sea floor, 


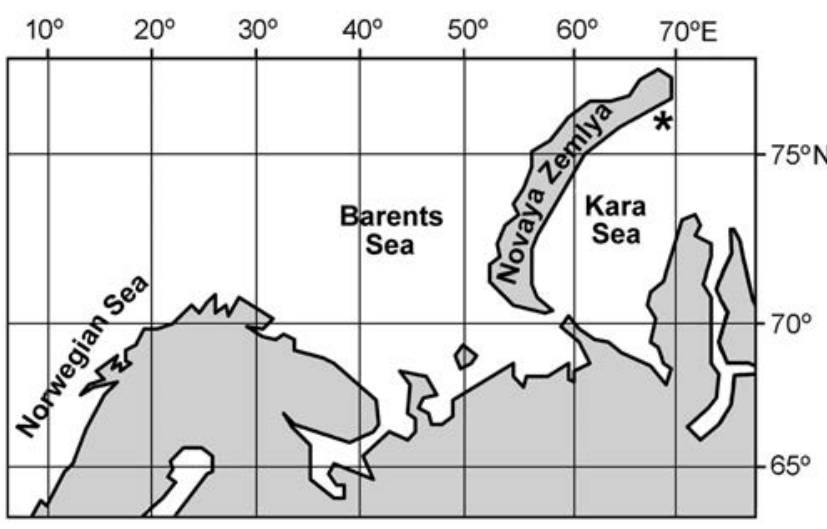

Figure 1. Map showing the collection site (at asterisk) of the holotype of Coleodesmium karaensis n. gen. n. sp.

although some individuals of Allapasus aurantiacus are known to burrow shallowly. Moreover, most, and possibly all, torquaratorids can ascend into the water above the sea floor and drift from one place to another.

Here, we use ribosomal DNA sequence and morphology to characterize an acorn worm from the Russian Kara Sea as new genus and species: Coleodesmium karaensis within the family Torquaratoridae. The holotype, collected from a depth of about $350 \mathrm{~m}$ (the shallowest for any known torquaratorid), is a female with developing embryos adhering to her epidermal surface. This is the first clear instance of external brooding ever found in the phylum Hemichordata.

\section{Materials and Methods}

In the autumn of 2011, a single acorn worm was recovered from a Sigsbee trawl during cruise 59 of the R/V Akademik Mstislav Keldysh. The specimen was collected at station 5051 (Fig. 1, asterisk), which sampled the floor of the Kara Sea, near the north end of the Novaya Zemlya Trough (Russian Arctic). The trawling depth ranged from 340 to $351 \mathrm{~m}$. After reaching the deck, the freshly collected worm (which had lost about a third of its posterior end) was photographed under xenon strobe illumination and then divided into a minor and a major portion. The former was fixed in $95 \%$ ethanol for molecular analysis and the latter was fixed in $10 \%$ formalin in seawater for morphological study.

Genomic DNA was obtained by AutoGenprep965 proteinase K/phenol extraction (AutoGen, Inc., Holliston, MA). The amplification and sequencing of partial $16 \mathrm{~S}$ and complete $18 S$ rDNA were according to Osborn et al. (2012). The sequences from the Kara Sea enteropneust were approximately 500 base pairs of $16 S$ rDNA (GenBank KC907711) and about 1700 base pairs of 185 rDNA (GenBank KC907710). The sequences used in our analysis are enumerated in Table 1. Sequences were aligned with MuSCLE
3.6 (Edgar, 2004) as implemented in Geneious 6.0.5 (Biomatters, Auckland, NZ). The best-fit model $(\mathrm{GTR}+\mathrm{G}+\mathrm{I})$ was chosen using jModelTest (Posada, 2008). A 95\% majority rule consensus tree for hemichordates (40 million generations) was constructed from concatenated, but unlinked nucleotide sequences (with no regions excluded) in MrBayes 3.2.1 run on the Smithsonian Institution's Hydra cluster in replicate. AWTY (Wilgenbusch et al., 2004) was used to determine if a sufficient number of generations had been completed for posterior probabilities to stabilize, as well as to determine the amount of required burn-in before inferences from the Markov Chain Monte Carlo data sets were made. The first $10 \mathrm{~K}$ trees were removed as burn-in (20 million generations), leaving $10 \mathrm{~K}$ trees for inference $(20$ million generations). Clades containing replicate individuals for a single species are labeled only a single time in the resulting tree with a triangle whose length represents the branch lengths within the clade. Maximum likelihood analyses were run using RAxML-MPI parallels version (Stamatakis, 2006) on the Smithsonian Institution's Hydra cluster. One thousand replicate best-tree searches were run and 1000 standard bootstraps. Searches were run using both the $\mathrm{GTR}+\mathrm{G}+\mathrm{I}$ and GRT $+\mathrm{G}$ models with no differences found between the results. Node support is expressed as posterior probability, bootstrap at respective nodes. Poorly supported nodes $(<95 \%$ pp) were collapsed.

For morphological study, the formalin-fixed portion of the specimen was photographed before being embedded in Paraplast wax for histological sectioning. Serial 12-m sections were stained in $0.1 \%$ aqueous azure A (Spicer, 1963). In Paraplast-embedded tissue, larger oocytes and embryos tend to shatter during sectioning. Therefore, small samples from the pharyngeal region of the holotype were embedded in Spurr's resin, sectioned at $4 \mathrm{~mm}$ with a glass knife, and stained in aqueous $0.1 \%$ azure A with $0.1 \%$ sodium borate added. Serial sections of these tissue samples included two early embryos. Two additional embryos were studied by scanning electron microscopy (SEM). Each was detached from the mother's body, dehydrated in an ethanol series, critical-point dried using $\mathrm{CO}_{2}$, mounted on stubs with double-sided tape, sputter-coated with a gold-palladium mixture, and imaged by SEM. After SEM photography, the specimens were embedded in Spurr's resin and serially sectioned.

\section{Results}

\section{Taxonomy}

Phylum Hemichordata Bateson, 1885.

Class Enteropneusta Gegenbaur, 1870.

Family Torquaratoridae Holland et al., 2005 (as re-diagnosed in Osborn et al., 2012).

Genus Coleodesmium n. gen. Type and only species: Coleodesmium karaensis sp. $\mathrm{n}$. 
Table 1

\begin{tabular}{|c|c|c|c|c|}
\hline & $18 S$ & $16 S$ & Voucher & Citation \\
\hline \multicolumn{5}{|l|}{ Torquaratoridae } \\
\hline Yoda purpurata (I171-36a) & JN886757 & JN886740 & NHMUK 2011.5 & Osborn et al., 2012 \\
\hline Yoda purpurata (I171-36b) & JN886758 & JN886741 & NHMUK 2011.6 & Osborn et al., 2012 \\
\hline Yoda purpurata (I174-43a) & JN886759 & JN886742 & NHMUK 2011.9 & Osborn et al., 2012 \\
\hline Genus B sp. 1 (T879-A8) & JN886760 & EU520500 & SIO-BIC H11 & Osborn et al., 2012/Holland et al., 2009 \\
\hline Genus B sp. 1 (T879-A10) & EU520513 & EU520501 & SIO-BIC H12 & Holland et al., 2009 \\
\hline Genus B sp. 1 (D176-A1) & JN886761 & JN886744 & SIO-BIC H15 & Osborn et al., 2012 \\
\hline Genus B sp. 1 (D176-A5) & JN886762 & JN886745 & SIO-BIC H16 & Osborn et al., 2012 \\
\hline Genus B sp. 1 (D176-A2) & JN886763 & JN886746 & SIO-BIC H17 & Osborn et al., 2012 \\
\hline Genus B sp. 2 (T1013-A8) & EU520514 & EU520502 & SIO-BIC H13 & Holland et al., 2009 \\
\hline Genus B sp. 2 (T1011) & EU520515 & EU520503 & SIO-BIC H14 & Holland et al., 2009 \\
\hline Genus B sp. 2 (D177-A28) & JN886764 & JN886747 & SIO-BIC H18 & Osborn et al., 2012 \\
\hline IFREMER Enteropneust & EU728438 & EU728431 & na & Cannon et al., 2009 \\
\hline Genus C sp. 1 (T886-A4) & EU520511 & EU520499 & SIO-BIC H10 & Holland et al., 2009 \\
\hline Genus C sp. 1 (T1012-A8) & EU520510* & EU520498 & SIO-BIC H9 & Holland et al., 2009 \\
\hline Genus C sp. 1 (D80-A2) & JN886768 & JN886751 & SIO-BIC H19 & Osborn et al., 2012 \\
\hline Coleodesmium karaensis n. gen. \& sp. & КC907710 & KC907711 & SIO-BIC H27 & This paper \\
\hline Allapasus aurantiacus (T438) & JN886765 & JN886748 & SIO-BIC H2O & Osborn et al., 2012 \\
\hline Allapasus aurantiacus (D98-pc66) & JN886767 & JN886750 & na & Osborn et al., 2012 \\
\hline Allapasus isidis (I174-43b) & JN886766 & JN886749 & NHMUK 2011.7 & Osborn et al., 2012 \\
\hline Tergivelum baldwinae (T1094) & EU520509 & EU520497 & SIO-BIC H8 & Holland et al., 2009 \\
\hline Tergivelum baldwinae (T10781) & JN886772 & EU520495 & MNHN E24 & Osborn et al., 2012/Holland et al., 2009 \\
\hline Tergivelum cinnabarinum (I163-17) & JN886769 & JN886752 & NHMUK 2011.2 & Osborn et al., 2012 \\
\hline Tergivelum cinnabarinum (I165-24) & JN886770 & JN886753 & NHMUK 2011.3 & Osborn et al., 2012 \\
\hline Tergivelum cinnabarinum (I168-28) & JN886771 & JN886754 & NHMUK 2011.4 & Osborn et al., 2012 \\
\hline \multicolumn{5}{|l|}{ Ptychoderidae } \\
\hline Balanoglossus carnosus a & D14359 & na & na & Wada \& Satoh, 1994 \\
\hline Balanoglossus carnosus b & JF900489 & na & MCZ DNA103790 & Worsaae et al., 2012 \\
\hline Balanoglossus clavigerus & na & EU728425 & na & Cannon et al., 2009 \\
\hline Glossobalanus berkeleyi & EU728435 & EU728426 & na & Cannon et al., 2009 \\
\hline Glossobalanus minutus & AF119089 & na & MCZ DNA100058 & Giribet et al., 2000 \\
\hline Ptychodera bahamensis a & AF236802 & na & na & Cameron et al., 2000 \\
\hline Ptychodera bahamensis $\mathrm{b}$ & JF900485 & JX855285 & MCZ DNA101771/4 & Worsaae et al., 2012 \\
\hline Ptychodera bahamensis c & JF900486 & na & MCZ DNA103686 & Worsaae et al., 2012 \\
\hline Glossobalanus minutus & AF119089 & na & MCZ DNA100058 & Giribet et al., 2000 \\
\hline Ptychodera flava a & AF278681 & EU728428 & na & Winchell et al., 2002/Cannon et al., 2009 \\
\hline Ptychodera flava $\mathrm{b}$ & EU728436 & EU728429 & na & Cannon et al., 2009 \\
\hline "Ptychoderid sp. Tampa" & AF278685 & EU728427 & na & Winchell et al., 2002/Cannon et al., 2009 \\
\hline \multicolumn{5}{|l|}{ Unknown Family } \\
\hline "Tornaria larva" & EU728438 & EU728430 & na & Cannon et al., 2009 \\
\hline \multicolumn{5}{|l|}{ Spengelidae } \\
\hline Glandiceps hacksi & JN886773 & JN886755 & HUM-HEMI-001 & Osborn et al., 2012 \\
\hline Glandiceps abyssicola & KC776731 & KC776732 & SIO-BIC H28 & Holland et al., 2013 \\
\hline \multicolumn{5}{|l|}{ Harrimaniidae } \\
\hline Harrimania planktophilus & AF236799 & EU728421 & na & Cameron et al., 2000/Cannon et al., 2009 \\
\hline Harrimania kupfferi & JF900487 & JX855286 & MCZ DNA103688 & Worsaae et al., 2012 \\
\hline Meioglossus psammophilus & JF900488 & JX855287 & ZMUC-ENP-1 & Worsaae et al., 2012 \\
\hline Protoglossus koehleri & EU728432 & EU728420 & na & Cannon et al., 2009 \\
\hline Saccoglossus bromophenolosus & AF236801 & na & na & Cameron et al., 2000 \\
\hline Saccoglossus kowalevskii & L28054 & na & na & Turbeville et al., 1994 \\
\hline Saccoglossus pusillus & AF236800 & EU728422 & na & Cameron et al., 2000/Cannon et al., 2009 \\
\hline Saxipendium coronatum & EU728433 & EU728423 & na & Cannon et al., 2009 \\
\hline Saxipendium coronatum & EU520505* & EU520493 & SIO-BIC H4 & Holland et al., 2009 \\
\hline Saxipendium implicatum (D176-A11) & JN886774 & JN886756 & SIO-BIC H21 & Osborn et al., 2012 \\
\hline
\end{tabular}


Table 1 (Continued)

\begin{tabular}{|c|c|c|c|c|}
\hline & $18 S$ & $16 S$ & Voucher & Citation \\
\hline \multicolumn{5}{|l|}{ Pterobranchia } \\
\hline Cephalodiscus densus & EU728439 & na & na & Cannon et al., 2009 \\
\hline Cephalodiscus gracilis & AF236798 & na & na & Cameron et al., 2000 \\
\hline Cephalodiscus hodgsoni & EU728441 & na & na & Cannon et al., 2009 \\
\hline Cephalodiscus nigrescens & EU728440 & na & na & EU728440 \\
\hline Rhabdopleura normani & U15664* & na & na & Halanych, 1995 \\
\hline \multicolumn{5}{|l|}{ Echinodermata } \\
\hline Asteriodea, Asterias forbesii & DQ060776 & DQ297073 & AMCC 113321 & Janies, 2005 unpublished \\
\hline Crinoidea, Bathycrinus sp. & AY275891 & na & D1425 & Cohen et al., 2004 \\
\hline Crinoidea, Neogymnocrinus richeri & AY275895 & na & D1363 & Cohen et al., 2004 \\
\hline Echinoidea, Aspidodiadema jacobi & DQ073780 & DQ073734 & na & Smith et al., 2006 \\
\hline Holothuroidea, Parastichopus californicus & DQ777084 & DQ777096 & AMCC 113282 & Janies, 2005 unpublished \\
\hline Ophiuroidea, Ophioderma brevispinum & DQ060803 & DQ297103 & na & Janies, 2005 unpublished \\
\hline
\end{tabular}

* Partial sequence.

Etymology: The generic name derives from Greek koleos, "sheath," combined with desmos, "cord," in recognition of the diagnostic anatomical feature described in the next section.

Generic diagnosis: Part of the proboscis skeleton is a tubular sheath immediately surrounding the collar nerve cord for most of its length; the sheath is four to five times thicker than the extracellular basal lamina described around the collar cords of other enteropneusts.

Coleodesmium karaensis n. sp. (Figs. 3-5). Holotype (female) collected by the benthos team of the P. P. Shirshov Institute of Oceanology on 1 October 2011 during cruise 59 of the R/V Akademik Mstislav Keldysh at station 5051 (latitude $75.81^{\circ} \mathrm{N}-75.83^{\circ} \mathrm{N}$, longitude $68.99^{\circ} \mathrm{E}-69.01^{\circ} \mathrm{E}$ ) in the Novaya Zemlya Trench, Kara Sea, Russian Arctic. The collection was by Sigsbee trawl, at a depth between 340 and $351 \mathrm{~m}$. Histological sections are conserved in the Scripps Institution of Oceanography Benthic Invertebrate Collection as SIO-BIC-H27. There are no paratypes.

Specific diagnosis: The same as for the genus.

Etymology: the species name, karaensis, is a latinized adjective referring to the Kara Sea, where the holotype was collected.

\section{Phylogenetic analysis}

Coleodesmium karaensis n. gen n. sp. is clearly a member of the deep-sea family Torquaratoridae (Fig. 2). Coleodesmium karaensis n. gen. n. sp. is genetically most closely related to another new species that was originally designated "genus C" by Osborn et al. (2012). Gross morphology, as seen on remotely operated vehicle video (Osborn et al., 2012, fig. 1J) supports the idea of these being closely allied species, but the nature of the relationship cannot be determined without careful morphological examination of a specimen of genus C sp. 1. Genus C sp. 1 was collected off Oregon on three separate occasions (Osborn et al., 2012), but none of those specimens were properly photo-documented or fixed to allow morphological description. There is moderate support for a close relationship between Tergivelum, Allapasus, genus C, and Coleodesmium (Fig. 2). The genetics and anatomical features of the Kara Sea enteropneust (described below) were sufficiently different from other known torquaratorids to justify naming it Coleodesmium karaensis n. gen. n. sp.

\section{External anatomy of holotype}

Figure 3A shows a dorsal view of the portion of the freshly collected holotype recovered in the trawl. The recovered part of the body before fixation was $6.3 \mathrm{~cm}$ long and comprised a proboscis (Pr), collar (Co), and about two-thirds of the trunk (Tr); the posterior part of the hepatic intestinal region and the entire post-hepatic intestinal region were missing. All body regions of the fresh specimen were translucent and almost colorless (at most, lightly tinged with a lavender color).

Before fixation, the proboscis was dome-shaped $(0.9 \mathrm{~cm}$ long by a maximum width of $1.2 \mathrm{~cm}$ ) with longitudinal grooves mid-dorsally and mid-ventrally. The collar $(0.5 \mathrm{~cm}$ long by $1.4 \mathrm{~cm}$ wide) was characterized by a transverse opaque stripe (Fig. 3A, white arrowhead) and had a longitudinal groove mid-dorsally that deepens and widens posteriorly. The recovered portion of the trunk was $4.8 \mathrm{~cm}$ long by a maximum width of $1.3 \mathrm{~cm}$. All along either side of the trunk, lateral wings arose and curled dorsally, such that their edges were apposed at a mid-dorsal seam (Fig. 3A, black arrowhead). In the pharyngeal region of the trunk, creamcolored oocytes and embryos were clearly visible through the translucent body wall (some examples are indicated by arrows in Fig. 3A). The appearance of the holotype after formalin fixation is shown in Figures 3B-D. The boxes in Figure $3 \mathrm{~B}$ indicate which regions were prepared histologically. Figure $3 \mathrm{C}$ shows the gill pores running on either side 


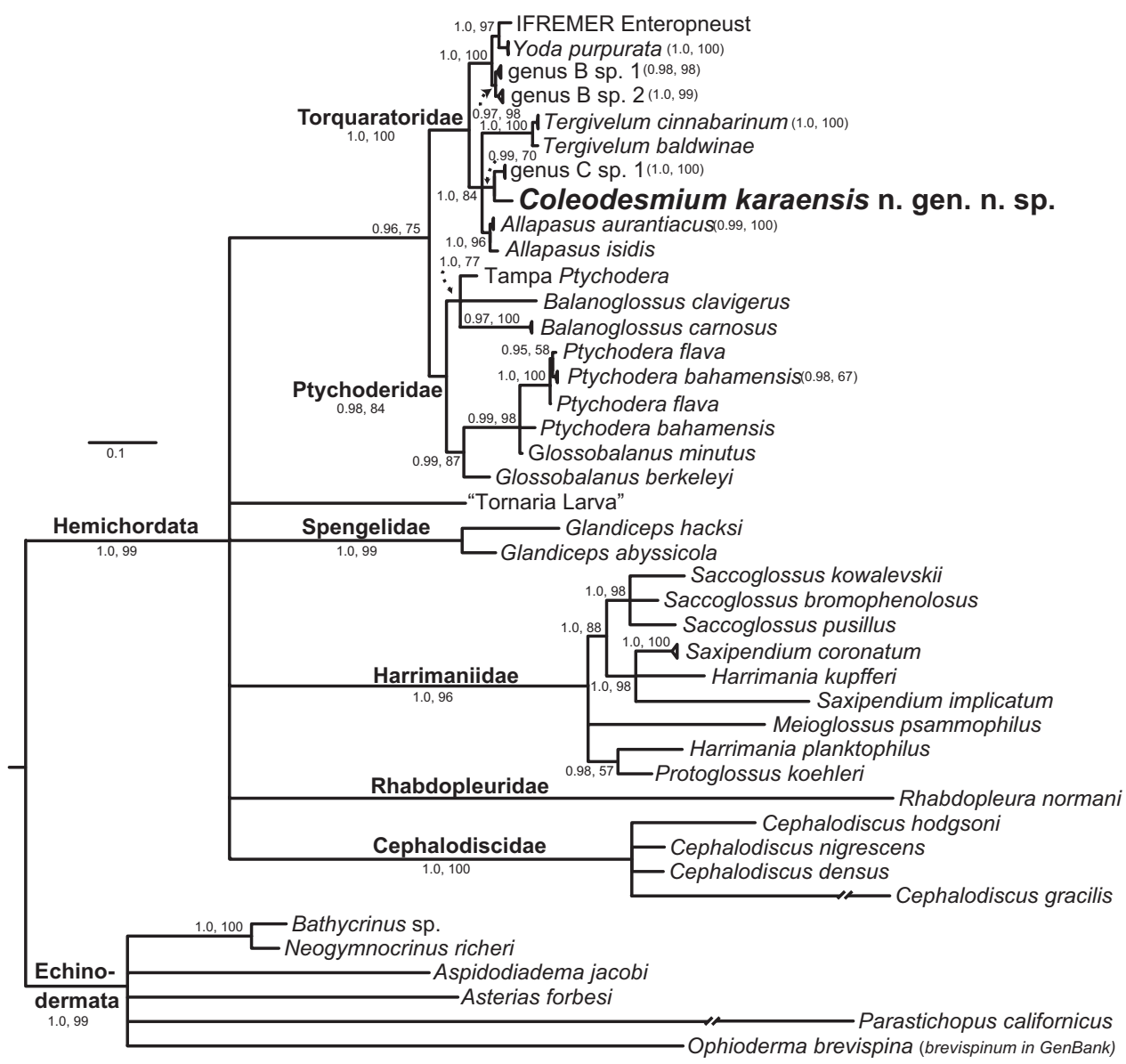

Figure 2. Phylogenetic analysis of phylum Hemichordata based on concatenated, unlinked $16 \mathrm{~S}$ and $18 \mathrm{~S}$ rDNA sequences. This is a $95 \%$ majority rule consensus tree from the final 40-million-generation Bayesian analysis. At the top left, the scale bar indicates the number of substitutions per nucleotide site. Branches with less than 0.95 posterior probability were collapsed, and species with more than one exemplar sequence are shown as cartooned clades (triangles whose width indicates genetic distance within the clade; see Table 1 for number of individuals included in each). Node support is shown as posterior probability, ML bootstrap (from the final RAxML analysis using the GTR $+\mathrm{G}$ model with 1000 best tree searches and 1000 bootstrap replicates).

of the dorsal nerve cord in the pharyngeal region of the trunk after the removal of the lateral wings, and the arrowhead in Figure 3D shows the prominent mid-ventral groove that runs along the ventral side of the trunk.

\section{Internal anatomy of holotype}

Some of the tissues of the holotype were damaged during capture and fixation. In addition, the abundant mucus in the epidermal cells swelled during histological processing, and large amounts ruptured outward onto the microscope slide or inward into the subepidermal tissue, especially in the proboscis. A cross section through the proboscis (Fig. 4A) shows the dorsal and ventral grooves. Internally, the proboscis is filled with a loose mesh of smooth muscles and connective tissue fibers. Part of the mesh is relatively condensed and organized into a thin, horizontally oriented sheet (Fig. 4A, arrowhead) running along most of the length of the proboscis. The proboscis musculature in C. karaensis is strikingly less developed than in the genus Allapasus and thus is a useful criterion for distinguishing between the similarly shaped worms in these two genera. No spacious protocoel, pericardial cavity, or coelomopores were detected. In the proboscis, the basal concentration of neurites of the intraepidermal nervous system comprise a neuropil that is inconspicuous except posteriorly, where it thickens on either side of the midline of the proboscis stalk (Fig. 4B, arrows; $4 \mathrm{C}$, asterisk). Posteriorly, these thickened regions of neuropil merge before connecting with the dorsal collar cord.

The collar region epidermis is especially rich in mucous cells and is underlain by a sparse network of smooth muscle cells and connective tissue fibers; no coelomopores were detected. The gut in this body region is the buccal cavity (Fig. 4D, asterisk). At the anterior end of the collar, the 

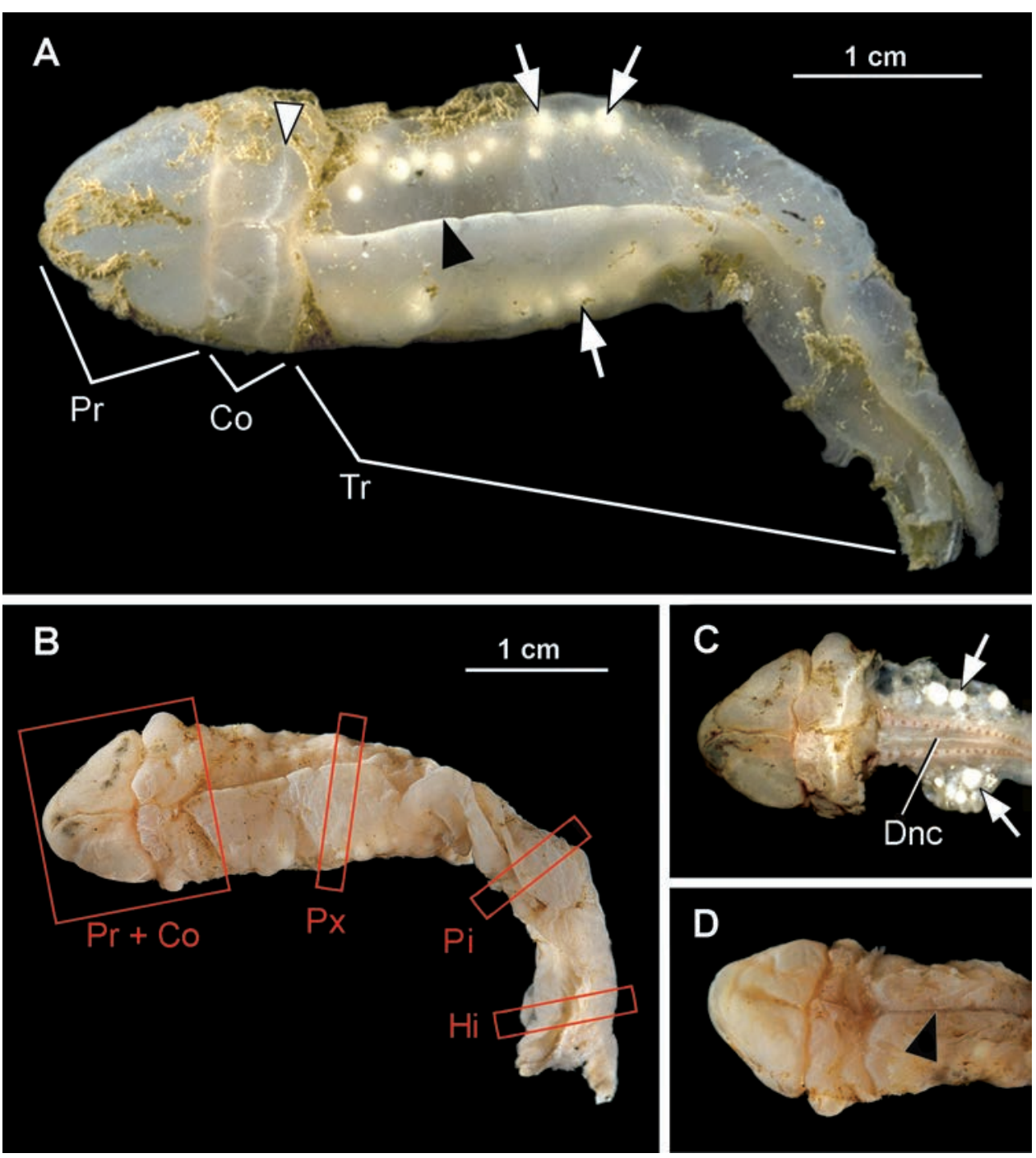

Figure 3. Coleodesmium karaensis n. gen. n. sp. (A) Dorsal view of the living holotype, showing proboscis (Pr), collar (Co), and trunk (Tr; posterior part missing); the white arrowhead indicates the transverse stripe on the collar; the black arrowhead indicates the mid-dorsal apposition of the left and right lateral wings accompanying the trunk; and the white arrows indicate large oocytes or embryos visible through the translucent body wall. Photo by Tina Molodtsova, P.P. Shirshov Institute of Oceanology RAS, used with permission. (B) Dorsal view after fixation indicating regions prepared as serial histological sections: proboscis + collar $(\mathrm{Pr}+\mathrm{Co})$; pharynx (Px), prehepatic intestine (Pi), and hepatic intestine (Hi). (C) Anterior part of B after removal of most of the lateral wings to expose the dorsal nerve cord of the trunk (Dnc) accompanied on either side by a row of gill pores; the arrows indicate large oocytes or embryos, respectively on or within the remnants of the lateral wings. (D) Ventral view of anterior body after fixation; along the trunk, a midventral groove (arrowhead) is conspicuous. The scale line in B is also applicable to C and D.

collar cord (Fig. 4D, arrowhead) opens to the exterior via a broad anterior neuropore. At this level, there is also a stomochord packed with vacuolated cells (Fig. 4D, arrow). The ventral side of the stomochord is associated with small glomeruli (Fig. 4E, arrowheads). In the mid-collar, the collar cord (Fig. 4F, arrowhead) has an inconspicuous lumen and lacks dorsal roots. Strikingly, the cord runs within a conspicuous sheath of extracellular material (especially dorsally and laterally) that can be considered an extension of the proboscis skeleton. This feature sets C. karaensis apart from other enteropneusts described to date. Just ventral to the stomochord are the perihaemal coeloms (Fig. 4F, asterisks) largely occupied by longitudinal muscle fibers. The stomochord (Fig. 4F, arrow) is still present ventral to the perihaemal coeloms.

Near the posterior end of the collar are plate-like elements of the proboscis skeleton (Fig. 4G, arrowheads). Unfortunately, the holotype's tissues, including the proboscis 
skeleton, are damaged at this level. This means the relationships between the plate-like elements and the skeletal sheath surrounding the collar cord cannot be determined for the holotype (although it is certain that no posterior horns are present). A short distance posterior to the cross-sectional level in Figure 4G, the stomochord and perihaemal coeloms disappear, and the collar cord emerges at the posterior neuropore to continue as the dorsal nerve cord of the trunk.

In the trunk, the epidermis includes abundant mucous cells, and the mesoderm comprises a sparse network of smooth muscles and connective tissue fibers, as in the more anterior body regions. Lateral wings arise along each side of the trunk (mostly removed in Fig. 4H; damaged in Fig. 4I, but complete in Fig. 4J). The wing on either side curls dorsally and closely apposes itself to its counterpart at a mid-dorsal seam. In the pharyngeal region of the trunk, removal of the lateral wings exposes about two dozen gill pores running on either side of the dorsal nerve cord (Fig. $3 \mathrm{C})$. The dorsal nerve cord is underlain by the dorsal blood vessel (Fig. 4H, arrow). Internally, the gill slits facing the pharyngeal lumen are supported by alternating primary and secondary gill bars (Fig. 4H, twin arrows) not connected by synapticles. The pharyngeal lumen is not separated into a dorsal respiratory and a ventral digestive region. The pharyngeal region of the trunk is deeply indented by a ventral groove, along which runs the ventral nerve cord underlain by the ventral blood vessel (Fig. 4H, arrowhead).

The holotype is a female (presumably C. karaensis has separate sexes, although no male has yet been found). The ovaries (Fig. 4H, tandem arrows) lie just beneath the epidermis covering the dorsal side of the pharyngeal region of the trunk and the concave sides of the lateral wings in the same body region. Each ovary contains a single primary oocyte that can range in diameter from a few micrometers up to about a millimeter (Fig. 5A). Each primary oocyte is characterized by a large vesicular nucleus containing a single prominent nucleolus. The largest oocytes cause an outward bulge of the epidermis but are not externalized in epidermal pouches as they are in acorn worms of the genus Allapasus (the latter were described by Holland et al., 2012b).

In the intestinal regions of the trunk, there is still a ventral groove, but it is much shallower than that of the pharyngeal region. The lining epithelium of the prehepatic gut is corrugated into plicae (Fig. 4I). By contrast, the succeeding hepatic intestine (Fig. 4J) is characterized dorsally by larger-scale outpocketings (hepatic sacculations) oriented perpendicular to the long axis of the body (Fig. 4K). In the holotype, the only gut region containing luminal contents was the hepatic intestine. The ingested material was brownish and consisted largely of unidentifiable fibrogranular material very sparsely mixed with skeletal fragments from sponges, echinoderms, foraminifera, and diatoms. In many places, the gut contents were organized into compact spheres (Fig. 4K, arrowhead) that may possibly have been ingested fecal pellets of other organisms. As already mentioned, the trunk regions housing the posterior part of the hepatic intestine and the entire posthepatic intestine were broken off and lost during collection.

\section{Externally brooded embryos}

The female holotype of $C$. karaensis bears about a dozen embryos on the pharyngeal region of her trunk. Each is recessed in an epidermal depression (Fig. 5B) on the dorsal side of the body or on the concave (medial) side of the lateral wings. The ovoid embryos have an average diameter of about $1.2 \mathrm{~mm}$ (Fig. 5C). Each of the four embryos studied by embedding in Spurr's resin, by SEM, or both, comprised an ectoderm and endoderm and had a closed blastopore. Each of the thousands of ectodermal cells bore a single cilium on its outer surface (Fig. 5C-E), but no obvious ciliated bands were visible. Three of the sampled embryos were late gastrulae, with an archenteron filled with granular material, but not forming coeloms (data not shown). In the fourth embryo, an anterior coelomic space (Fig. 5F, single asterisk) was beginning to form by constriction from the archenteron (Fig. 5F, twin asterisks). A thin, single-layered membrane encloses each embryo (visible in part in Fig. 5B and intact in Fig. 5F, arrow). Whether the membrane represents a fertilization envelope or is derived from the maternal tissues is not known.

\section{Discussion}

\section{Morphology}

The proboscis skeleton of a hemichordate is a localized, conspicuous thickening of the extracellular matrix (= basal lamina) that delimits epithelia throughout the body. This material is tough but pliable after fixation. Admittedly, it is subjective just where to draw the line between skeleton and basal lamina. In Coleodesmium karaensis, the extracellular matrix surrounding the collar nerve is $30 \mu \mathrm{m}$ thick (except where it thins on the ventral side); this contrasts with the thinness of the extracellular matrices associated with the collar cord of other enteropneusts, which was 4 to $7 \mu \mathrm{m}$, where the published pictures are large enough and clear enough to permit a good measurement. The collar does not extend beyond the cord in either direction.

\section{Ecology}

The Kara Sea (Fig. 1) experiences 24-h polar days in summer and 24-h polar nights in winter. In most years, the ice cover persists for about 9 months (October through June). Much of the Kara Sea is shallower than $50 \mathrm{~m}$, and its southern region is complexly influenced by seasonal input of river water from the Russian mainland (e.g., Vetrov and Romankevich, 2011; Kozlovskiy et al., 2011), which 

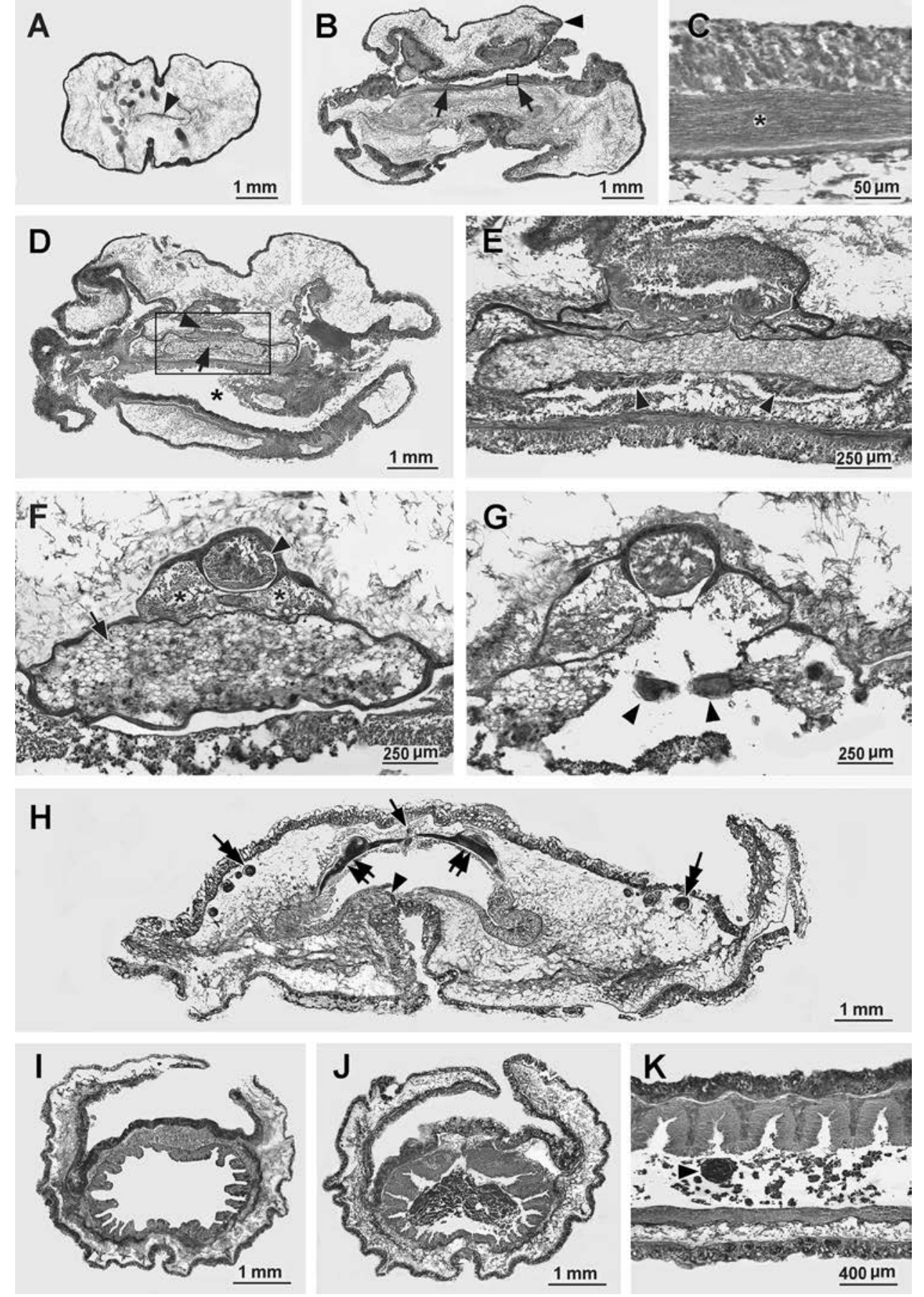

Figure 4. Coleodesmium karaensis n. gen. n. sp. Histological cross (A-J) or sagittal (K) sections. (A) Proboscis; arrowhead indicates relatively condensed mesh of smooth muscles and connective tissue fibers organized into a horizontally oriented sheet. (B) Anterior extremity of collar (arrowhead) overhanging the base of the proboscis stalk; arrows indicate the thickened neuropil dorsolaterally. (C) Enlargement of boxed region in B, showing detail of epidermis including basal thickening of the neuropil of the intraepidermal nervous system (asterisk). (D) Section through the buccal cavity (asterisk), collar cord (arrowhead), and stomochord (arrow) near the level of the anterior neuropore. (E) Enlargement of box in D showing inconspicuous glomeruli (arrowheads) associated with the ventral side of the stomochord. (F) Collar nerve cord (arrowhead) surrounded by an extension of the proboscis skeleton; asterisks indicate perihaemal coeloms, and arrow indicates stomochord. (G) Damaged section near posterior extremity of collar; likely plate-like portion of proboscis skeleton indicated by arrowheads. (H) Pharyngeal region of trunk showing dorsal haemal vessel (arrow), ventral haemal vessel (arrowhead), gill 
strongly impacts the survivorship and other aspects of the ecology of the benthic invertebrates there (Fetzer and Arntz, 2008). By contrast, oceanographic conditions in the northwestern part of the Kara Sea fluctuate less markedly. The Novaya Zemlya Trough, which has maximum depths around $400 \mathrm{~m}$, is a conspicuous feature in the northwest, running parallel to the eastern shore of Novaya Zemlya Island. The oceanographic conditions in the trough are influenced by influx of Atlantic water traversing the Barents Sea and then rounding the northern tip of Novaya Zemlya. Although there are dynamic seasonal changes in mixing of water masses in the Novaya Zemlya Trough (Loeng et al., 1997), the bottom water there is characterized by high salinities and low temperatures (about $0 \pm 1.5^{\circ} \mathrm{C}$ ) all year long. At the collection site for C. karaensis (station 5051 during cruise 59 of the R/V Akademik Mstislav Keldysh), the salinity was 34.6 parts per thousand, and the water temperature was $-1.4{ }^{\circ} \mathrm{C}$ at a depth of about $350 \mathrm{~m}$ on 1 October 2011.

The sediment recovered in the trawl with the holotype of C. karaensis was brown ooze and clay, which is typical of the floor of the Novaya Zemlya Trough (Galkin et al., 2010), and included many specimens of an epibenthic foraminifera (Saccorhyza ramosa). Although the collection depth of 340-351 m was considerably less than abyssal, the low temperature and perpetual darkness there are comparable to those conditions in the deep-sea generally. Coleodesmium karaensis is the shallowest-living torquaratorid discovered so far and is possibly an example of the highlatitude emergence that was previously noted for some other benthic animals of the Novaya Zemlya Trough by Filatova and Zenkevich (1957)—for example, the holothurian Elpidia glacialis Théel, 1876.

Because the holotype of $C$. karaensis was collected in a trawl, it is not known whether the worm was captured while inhabiting a burrow (like some specimens of Allapasus aurantiacus) or while exposed on the sediment surface like most torquaratorids described to date. The relatively poorly developed body musculature of $C$. karaensis, as compared to $A$. aurantiacus, indicates that the former might well live epibenthically and never burrow. The gut contents of $C$. karaensis were almost free of mineral grains, indicating that the worm feeds selectively, although nothing is known about the biomechanics of the deposit feeding or the identity of the foods providing major energy sources to the worm.

\section{Reproductive biology}

Coleodesmium karaensis is the first enteropneust species (and indeed the first hemichordate) ever found to brood embryos externally on the maternal surface. There is, however, an earlier report of internal brooding in an enteropneust by Gilchrist (1925), who published a drawing of a single advanced larva within the trunk coelom of an adult female of Xenopleura vivipara (family Harrimaniidae). Some enteropneust species, like Saccoglossus pusillus (Davis, 1908) as well as pterobranch hemichordates in the genera Cephalodiscus (Sciaparelli et al., 2004) and Rhabdopleura (Lester, 1988; Sato et al., 2008), retain early developmental stages in the maternal burrow or tube.

External brooding in C. karaensis raises a number of questions. First, do the females need to associate closely with conspecific males (presumed to exist) to effect fertilization? Second, where are the large female gametes located when they are fertilized-subepidermally or perhaps in externalized bag-like protrusions like those described for $\mathrm{Al}$ lapasus aurantiacus by Holland et al. (2012b)? Third, one could ask whether any nutrients are transferred from the mother to the brooded developmental stages (the voluminous yolk store in the full-grown oocytes would make this seem unlikely). Fourth, how advanced is the developmental stage that hatches from the enclosing membrane and leaves the mother worm? Fifth, do the hatchlings swim in the plankton and perhaps feed there (and, if so, do they resemble large tornaria larvae) or are they lecithotrophic direct developers that do not feed? Answers to these questions would require observations on additional specimens of $C$. karaensis from one of the world's least accessible habitats.

\section{Acknowledgments}

We are indebted to the crew of the R/V Akademik Mstislav Keldysh and to Sergey Galkin, Andrey Vedenin, Kirill Minin, and Tina Molodtsova for help with the dredging, sorting, and photography of the freshly collected worm. Greg Rouse kindly photographed the formalin-fixed specimen, and Linda Holland constructively criticized our manuscript. Matt Kweskin kindly facilitated use of the Smithsonian's Hydra cluster. This research was supported in part by the Russian foundation of Basic Research (grant number 12-05-33049).

Figure 4. (Continued) bars (twin arrows), and ovaries (tandem arrows); the lateral wings that would normally arch over the pharyngeal region are largely missing. (I) Prehepatic intestine with no gut contents; lateral wings are damaged. (J) Hepatic intestine with gut contents; lateral wings are intact. (K) Parasagittal view of hepatic intestine showing hepatic sacculations dorsally; the arrowhead indicates a possible ingested fecal pellet in the gut lumen. 

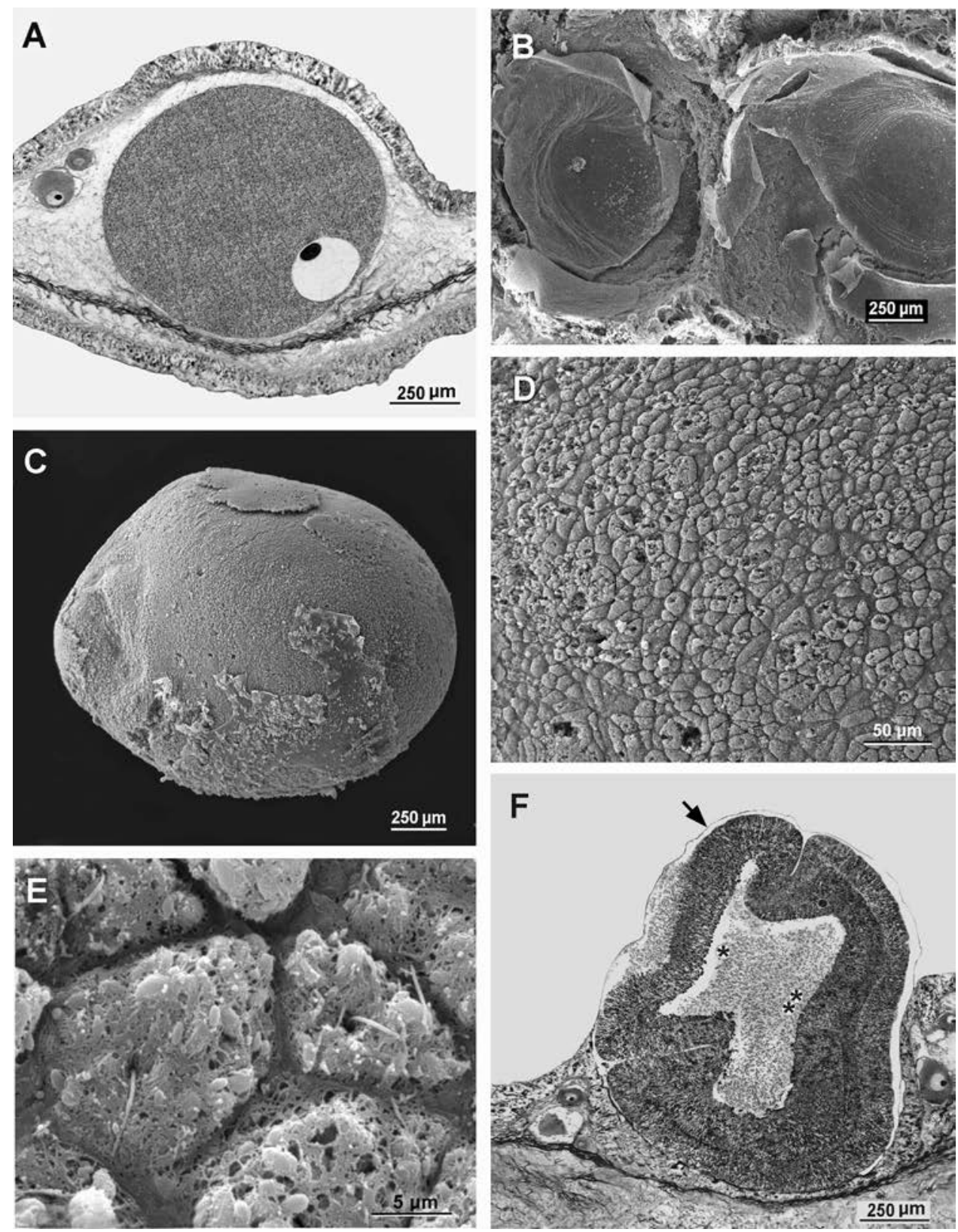

Figure 5. Coleodesmium karaensis n. gen. n. sp. (A) Section through part of a lateral wing (concave medial surface at top) in the pharyngeal region of the trunk, showing oocytes, one nearly maximum size. (B) Surface view of two concavities in the maternal epidermis from which brooded embryos have been removed. (C) Surface view of a gastrula removed from the maternal surface. (D) Enlarged surface view of $C$ showing outer surface of ectoderm. (E) Enlargement of D showing outer surfaces of several cells each bearing a single cilium. (F) Section through a brooded embryo surrounded by a thin membrane (arrow) and attached to the maternal epidermis (at bottom); the embryo's archenteron (twin asterisks) is constricting off the anterior coelomic cavity (single asterisk).

\section{Literature Cited}

Anderson, T. J., R. Przeslawski, and M. Tran. 2011. Distribution, abundance and trail characteristics of acorn worms at Australian continental margins. Deep-Sea Res. II 58: 970-978.

Bateson, W. 1885. Note on the later stages in the development of
Balanoglossus kowalevskii [sic] (Agassiz), and on the affinities of the Enteropneusta. Proc. R. Soc. 38: 23-30.

Belichov, D. V. 1971. Kishechnodyshashie (Enteropneusta) Kurilo-Kamchatskoj Vpadiny (Tuskarory), Glossobalanus tuscarorae n. sp. Vop. Zool., Ser. 2, Kazan Pedagogical Univ. 61: 3-38.

Cameron, C. B., J. R. Garey, and B. J. Swalla. 2000. Evolution of the 
chordate body plan: new insights from phylogenetic analyses of deuterostome phyla. Proc. Natl. Acad. Sci. USA 97: 4469-4474.

Cannon, J. T., A. L. Rychel, H. Eccleston, K. M. Halanych, and B. J. Swalla. 2009. Molecular phylogeny of Hemichordata, with updated status of deep-sea enteropneusts. Mol. Phylogenet. Evol. 52: 17-24.

Cohen, B. L., N. Ameziane, M. Eleaune, and B. Richer de Forges. 2004. Crinoid phylogeny: a preliminary analysis. Mar. Biol. 144: 605-617.

Davis, B. M. 1908. The early life-history of Dolichoglossus pusillus Ritter. Univ. Calif. Publ. Zool. 4: 187-226 + pl. IV-VIII.

Edgar, R. C. 2004. MUSCLE: multiple sequence alignment with high accuracy and high throughput. Nucleic Acids Res. 32: 1792-1797.

Fetzer, I., and W. E. Arntz. 2008. Reproductive strategies of benthic invertebrates in the Kara Sea (Russian Arctic): adaptation of reproduction modes to cold water. Mar. Ecol. Prog. Ser. 356: 189-202.

Filatova, Z. A., and L. A. Zenkevich. 1957. Kolichestvennoe raspredelenie donnoi fauny Karskogo Morya. Tr. Vses. Gidrobiol. O-va. 8: $3-62$.

Galkin, S. V., T. A. Savilova, L. I. Moskalev, and N. V. Kucheruk. 2010. Macrobenthos of the Novaya Zemlya Trough. Oceanology 50: 982-993.

Gegenbaur, C. 1870. Grundzüge der vergleichenden Anatomie. Zweite, umgearbeitete Auflage. Wilhelm Engelmann, Leipzig, 892 pp.

Gilchrist, J. D. F. 1925. Xenopleura vivipara g. et sp. n. (Enteropneusta). Q. J. Microsc. Sci. 69: 555-570.

Giribet, G., D. L. Distel, M. Polz, W. Sterrer, and W. C. Wheeler. 2000. Triploblastic relationships with emphasis on the acoelomates and the position of Gnathostomulida, Cycliophora, Platyhelminthes, and Chaetognatha: a combined approach of $18 \mathrm{~S}$ rDNA sequences and morphology. Syst. Biol. 49: 539-562.

Halanych, K. M. 1995. The phylogenetic position of the pterobranch hemichordates based on 18S rDNA sequence data. Mol. Phylogenet. Evol. 4: 72-76.

Holland, N. D., D. A. Clague, D. P. Gordon, A. Gebruk, D. L. Pawson, and M. Vecchione. 2005. "Lophenteropneust" hypothesis refuted by collection and photos of new deep-sea hemichordates. Nature 434: 374-376.

Holland, N. D., W. J. Jones, J. Ellena, H. A. Ruhl, and K. L. Smith. 2009. A new deep-sea species of epibenthic acorn worm (Hemichordata, Enteropneusta). Zoosystema 31: 333-346.

Holland, N. D., K. J. Osborn, and L. A. Kuhnz. 2012a. A new deep-sea species of harrimaniid enteropneust (Hemichordata). Proc. Biol. Soc. Wash. 125: 228-240.

Holland, N. D., L. A. Khunz, and K. J. Osborn. 2012b. Morphology of a new deep-sea acorn worm (Class Enteropneusta, Phylum Hemichordata): a part-time demersal drifter with externalized ovaries. J. Morphol. 273: 661-671.

Holland, N. D., K. J. Osborn, A. V. Gebruk, and A. Rogacheva. 2013. Rediscovery and augmented description of the H.M.S. Challenger acorn worm (Hemichordata, Enteropneusta), Glandiceps abyssicola, in the equatorial Atlantic abyss. J. Mar. Biol. Assoc. UK 93(8): doi: $10.1017 /$ S0025315413000684.

Hyman, L. H. 1959. The Invertebrates: Smaller Coelomate Groups, Vol. 5. McGraw-Hill, New York.

Kozlovskiy, V. V., M. V. Chikina, N. V. Kucheruk, and A. B. Basin. 2011. Structure of the macrozoobenthic communities in the southwestern Kara Sea. Oceanology 51: 1012-1020.

Lester, S. M. 1988. Ultrastructure of adult gonads and development and structure of the larva of Rhabdopleura normani (Hemichordata: Pterobranchia). Acta Zool. 69: 95-109.

Loeng, H., V. Ozhigin, and B. Ardlandsvik. 1997. Water fluxes through the Barents Sea. ICES J. Mar. Sci. 54: 310-317.
Osborn, K. J., L. A. Kuhnz, I. G. Priede, M. Urata, A. V. Gebruk, and N. D. Holland. 2012. Diversification of acorn worms (Hemichordata, Enteropneusta) revealed in the deep sea. Proc. R. Soc. B 279: 16461654

Posada, D. 2008. jModelTest: phylogenetic model averaging. Mol. Biol. Evol. 25: 1253-1256.

Priede, I. G., K. J. Osborn, A. V. Gebruk, D. Jones, D. Shale, A. Rogacheva, and N. D. Holland. 2012. Observations on torquaratorid acorn worms (Hemichordata, Enteropneusta) from the North Atlantic with descriptions of a new genus and three new species. Invertebr. Biol. 131: $244-257$.

Sato, A., J. D. D. Bishop, and P. W. H. Holland. 2008. Developmental biology of pterobranch hemichordates: history and perspectives. Genesis 46: 587-591.

Sciaparelli, S., R. Cattaneo-Vietti, and P. Mierzejewski. 2004. A "protective shell" around the larval cocoon of Cephalodiscus densus Anderson, 1907 (Graptolithoidea, Hemichordata). Polar Biol. 27: 813817.

Smith, A. B., D. Pisani, J. A. Mackenzie-Dodds, B. Stockley, B. L. Webster, and D. T. Littlewood. 2006. Testing the molecular clock: molecular and paleontological estimates of divergence times in the Echinoidea (Echinodermata). Mol. Biol. Evol. 23: 1832-1851.

Smith, K. L., N. D. Holland, and H. A. Ruhl. 2005. Enteropneust production of spiral fecal trails on the deep-sea floor observed with time-lapse photography. Deep-Sea Res. I 52: 1228-1240.

Spengel, J. W. 1893. Fauna und Flora des Golfes von Neapel und der angrenzenden Meeres-Abschnitte. Herausgegeben von der zoologischen Station zu Neapel. 18, Monographie: Enteropneusten. Friedländer, Berlin. 756 pp +37 pl.

Spicer, S. S. 1963. Histochemical differentiation of mammalian mucopolysaccharides. Ann. NY Acad. Sci. 106: 379-388.

Stamatakis, A. 2006. RAxML-VI-HPC: Maximum Likelihood-based Phylogenetic Analyses with thousands of taxa and mixed models. Bioinformatics 22: 2688-2690.

Théel, H. 1876. Note sur l'Elpidia, genre nouveau du groupe des holothuries. Bih. K. Svensk. Vet. Akad. Handl. 4 (4): 1-7.

Turbeville, J. M., J. R. Schulz, and R. A. Raff. 1994. Deuterostome phylogeny and the sister group of the chordates: evidence from molecules and morphology. Mol. Biol. Evol. 11: 648-655.

Vetrov, A. A., and E. A. Romankevich. 2011. Genesis of organic matter in the Kara Sea bottom sediments. Oceanology 31: 608-615.

Wada, H., and N. Satoh. 1994. Phylogenetic relationships among extant classes of echinoderms, as inferred from sequences of $18 \mathrm{~S}$ rDNA, coincide with relationships deduced from the fossil record. J. Mol. Evol. 38: 41-49.

Wilgenbush, J. C., D. L. Warren, and D. L. Swofford. 2004. AWTY: A system for graphical exploration of MCMC convergence in Bayesian phylogenetic inference. [Online]. Available: http://ceb.csit.fsu.edu/ awty [2013, October 8].

Winchell, D. J., J. Sullivan, C. B. Cameron, B. J. Swalla, and J. Mallatt. 2002. Evaluating hypotheses of deuterostome phylogeny and chordate evolution with new LSU and SSU ribosomal DNA data. Mol. Biol. Evol. 19: 762-776.

Woodwick, K. H., and T. Sensenbaugh. 1985. Saxipendium coronatum, new genus, new species (Hemichordata: Enteropneusta): the unusual spaghetti worms of the Galápagos hydrothermal vents. Proc. Biol. Soc. Wash. 98: 351-365.

Worsaae, K., W. Sterrer, S. Kaul-Strehlow, A. Hay-Schmidt, and G. Giribet. 2012. An anatomical description of a miniaturized acorn worm (Hemichordata, Enteropneusta) with asexual reproduction by paratomy. PLOS ONE 7(11): e48529. 